Frykberg, Erik R. and Joseph J. Tepas. “Terrorist Bombings: Lessons Learned from Belfast to Beirut." Annals of Surgery (November 1988).

Roccaforte, David J. and Erick J. Arbenz. "Surge Capacity and Disaster Preparedness for Definitive Care Areas." Sphere, v. 57/1 (January-March 2005).

U.S. Department of Defense (DOD). "Report of the DOD Commission on Beirut International Airport Terrorist Act, October 23, 1983.” Washington, DC: DOD,1983.

Allan S. Boyce U.S. Army Command and General Staff College

\section{Bhopal Chemical Disaster (1984)}

At five minutes after midnight on December 3, 1984 in the Union Carbide plant at Bhopal, India, nearly 40 tons of methyl isocyanate (MIC) gas leaked with no advance warning, and the city was blanketed with a highly toxic cloud. In the morning, there were 3,828 dead bodies littered in houses and on roads, along with the dead bodies of animals. The death toll mounted to 8,000 in three days. The hospitals were overflowing with desperately sick and dying people.

The initial effects of exposure were coughing, vomiting, feeling of suffocation, breathlessness, severe eye irritation, and stomach pains. According to Amnesty International, 22,000 people have since died of their injuries due to the disaster. The Bhopal Group for Information and Action estimates that 10 to 15 people are dying of their injuries every month. At the time of the disaster, 894,539 people were living in 56 wards in Bhopal. Thirty-six wards with a total population of 559,835 were declared affected by the gas. A compensation of 15.46 billion rupees ( $\$ 348$ million) was awarded to 574,304 people. More than 100,000 people continue to suffer chronic and debilitating illnesses for which treatment is largely ineffective. Despite the event, Bhopal is currently a thriving city, with a population of $1,836,784$ as measured by the 2001 census.

Within a week of the disaster, Warren Anderson, CEO of Union Carbide, flew to Bhopal and was soon arrested. He was released and allowed to go back to the United States on a bail of 25,000 rupees (about $\$ 600$ ), signing that he would attend court when summoned. Many U.S. lawyers arrived in Bhopal within a week of the disaster, obtaining power of attorney from nearly 400,000 victims. The media labeled them "ambulance chasers." In response, the government of India enacted the Bhopal Gas Leak Act of 1984, enabling the government to act as the legal representative of the victims in any claims arising from or related to the Bhopal disaster.

Initially, the government of India filed a claim in U.S. court for $\$ 3.3$ billion. However, after the visit of Indian Prime Minister Rajiv Gandhi to the United States, the government of India agreed to the out-of-court settlement with Union Carbide for only $\$ 490$ million, and absolving Union Carbide for all past, present, and future court proceedings. In a court case, the Supreme Court reversed the decision on criminal liability of Union Carbide, directing the Bhopal Criminal Court to proceed with the case. Union Carbide made a payment of $\$ 470$ million. Only a small portion of the compensation has actually been distributed to the victims due to legal and administrative procedures.

Paul Shrivastava, in his book Bhopal: Anatomy of a Crisis, states many countries of the world, including the United States and India, made a number of legal changes for safety after Bhopal. The government of India amended existing acts and passed a new Environmental Protection Act of 1986.

Satinath Sarangi and his Bhopal Group for Information and Action, as well as many other groups, have been in a sustained, 25-year struggle to get relief for the victims and have won many battles, but their struggle is not yet complete. They made a six-week, coast-to-coast padyatra (Hindi for "protest march on foot") in the United States and Canada.

See Also: Chemical Disasters; Diseases; History of Disaster Relief, India; International Law in the Prevention and Mitigation of Disasters; Laws.

\section{Further Readings}

Hanna, Bridget, Ward Morehouse, and Satinath Sarangi. The Bhopal Reader: Remembering Twenty Years of the World's Worst Industrial Disaster. Mapusa, Goa, India: Other India Bookstore, 2005.

Shrivastava, Paul. Bhopal: Anatomy of a Crisis. London: Paul Chapman Publishing, 1992.

Kailash Gupta

University of North Texas 